\title{
İllerin Ekonomik Gelişmişliği Üzerinde Yaratıcı Sınıfın Etkisi: Türkiye Örneği
}

Habibe Günsel Doğrul ${ }^{\mathrm{a}}$
Mediha Mine Çelikkol ${ }^{b}$

\section{Naci Murat ${ }^{\mathrm{c}}$}

Öz: Illerin ekonomik güçleri sahip oldukları fiziki sermayeleri kadar beşeri sermayelerine de bağlıdır. Bu çalışmada Florida'nın Yaratıcı Sınıf hipotezi, Türkiye bağlamında sınanmıştır. Bu amaçla, yapısal eşitlik modeli ve yol analizi kullanılarak beşeri sermaye ile bölgesel ekonomik gelişmişlik arasındaki ilişki incelenmiştir. Çalışmanın sonuçları, Florida'nın yüksek düzeydeki yaratıcılığın bölgesel ekonomik gelişmeyi teşvik ettiği teorisini teyit etmiştir. Ayrıca bulgular, yaratıcı sınıfin illerin ekonomik gelişmişliğini açıklamada eğitim düzeyine göre daha etkili olduğunu göstermiştir. Ek olarak, bulgular Türkiye'de il bazında sanatsal/kültürel alandaki yaratıcı bireylerin varlığı (bohem) ile beşeri sermayenin bölgesel dağılımı arasında pozitif ve istatistiksel olarak anlamlı ilişkiye işaret ederken, bölgede yaşamı kolaylaştıran imkanların ve üniversitenin ilin ekonomik gelişmişliği üzerinde istatistiksel olarak anlamlı bir etkiye sahip olmadığını da göstermiştir. Sonuç olarak, Florida'nın yaratıcı sınıfin coğrafi dağılımına ilişkin hipotezi Türkiye örneğinde tam olarak doğrulanamamıştır.

Anahtar Sözcükler: Beşeri Sermaye, Yaratıcı Sınıf, Bölgesel Ekonomik Gelişmişlik, Teknoloji, Yol Analizi ve Yapısal Eşitlikler Modeli

JEL Sınıflandırması: J24, R10, R20, O30

\section{The Effect of Creative Class on Economic Development of Cities: The Case of Turkey}

\begin{abstract}
Economic power of cities depends on their human capital as much as their pyhsical capital. Florida's hypothesis about Creative Class is tested in this study in the context of Turkey. For this purpose, we examine the relationsip between alternative mesures of human capital and regional development applying structural equation models and path analysis. Our results confirm Florida's hypothesis that high level of creativity fosters regional economic development. Evidence also suggest that total creative class seems to be better measurement than education in accounting for regional development across Turkish cities. In addition, our results suggest that while there is statistically significant association between the distribution of creative class and the presence of artistically culturally creative individuals (bohemians), there is no significant association with consumer amenities and university. As a result, Florida's hypothesis does not completely explain the distribution of creatives in the Turkish context.
\end{abstract}

Keywords: Human Capital, Creative Class, Regional Economic Development, Technology, Path Analysis and Structural Equations Model

JEL Classification: J24, R10, R20, O30

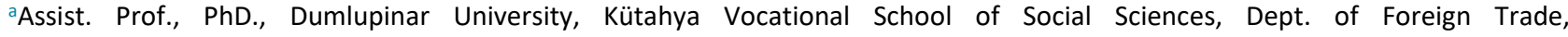
hgunsel.dogrul@dpu.edu.tr

${ }^{b}$ Assist. Prof., PhD., Dumlupinar University, Kütahya Vocational School of Social Sciences, Dept. of Finance-Banking and Insurance, mine.celikkol@dpu.edu.tr

'Assist. Prof., PhD., Ondokuz Mayis University, Faculty of Engineering, Dept. Of Industrial Engineering, nacimurat@omu.edu.tr
} 


\section{Giriş}

Geçmişle karşılaştııldığında piyasalarıyla, sermaye akışıyla farklı, yeni ve entegre bir varlık gösteren küresel bir ekonomik düzen ortaya çıkmıştr. Bu düzende insanın ekonomik sürece katkısı, ona sermaye niteliği kazandırmış ve "beşeri sermaye" kavramı ile ifade edilmiştir.

Günümüzde ekonomik büyümenin temel dinamiği olan beşeri sermayenin ülkeler, ülke içinde bölgeler, bölge içinde iller arasındaki gelişmişlik farklarının temel kaynaklarından biri olduğu kabul edilmektedir. Bir toplumun değer yargıları, dünya görüşü ile tüketim ve davranış kalıplarındaki değişmeleri içerecek biçimde toplumsal ve kurumsal yapıda dönüşüme yol açan büyümesi olarak tanımlanabilecek ekonomik kalkınma kavramının merkezine, beşeri sermayenin yerleştirilmesi yanlış olmayacaktır.

Beşeri sermayenin ekonomik gelişmişlik sürecinde etkin bir şekilde kullanılabilmesinin ve bu süreçte politikaların oluşturulabilmesinin yolu ise ölçümlenmesinden geçmektedir. Beşeri sermayenin ölçülmesinde kullanılan geleneksel ölçüt, eğitim olarak kabul edilmektedir. Eğitim, ekonomik ve sosyal ihtiyaçların karşılanması için gereken nitelikli işgücünün yetişmesinde, kalkınma hedeflerine göre değişen talep yapısına uygun beceri ve bilgilerin aktarılmasında, kaynakların genel olarak daha rasyonel bir biçimde ve verimli olarak kullanımasında, sağlıklı ve nitelikli istihdama hazır bir nüfusun oluşmasında en temel öğelerin başında gelmektedir (Eşiyok ve Sekmen, 2012). Eğitime yatrım yapan ve eğitimli insan gücüne sahip ülkelerin ekonomik gelişme sürecinde büyük bir avantaja sahip olduğu bir gerçektir. Ancak küresel ekonomik düzen ülkeleri, değişim yaşamaya zorlamaktadır.

Ülkeler küreselleşme sürecinde sanayi toplumundan bilgi toplumuna geçerek standart kitlesel üretim yerine katma değeri yüksek, yenilikçi, tasarım ağırlıklı esnek üretime yönelerek rekabet güçlerini arttırmaya çalışmaktadırlar. Bu noktada 21. yüzyılın kalkınma modelinin lokomotifinin yaratıcı endüstriler olduğu söylenebilir (UNCTAD, 2010). Yaratıcı endüstrilere konu olan yaratıcı faaliyetler, yaratıcılığı birincil girdi olarak kullanan mal ve hizmetlerin tasarım/yaratım, üretim ve dağıtım döngülerinin gerçekleştirildiği faaliyetlerdir. Bunlar, maddi mallar veya entelektüel hizmetler üreten, bilgiye dayalı faaliyetlerdir (UNCTAD, 2008). Yaratıcı ve yenilikçi faaliyetlerde çalışan ve bu çalışmaları nedeniyle gelir elde eden kişiler ise yaratıcı sınıfı oluşturmuşlardır. Bu oluşum, bilgiye dayanan veya yaratıcı mesleklerle ilişkilendirilen mesleğe-dayalı beşeri sermaye ölçütlerinin, beşeri sermaye birikimine etki eden unsurlar arasında eğitimin dışında değerlendirilmesi gerektiğini gündeme getirmiştir.

Yetenek ve yaratıcılığın ekonomik gelişmişlikteki rolüne olan ilgi, konunun ekonomi literatüründe tartışılır hale gelmesini sağlamıştır. Bölgesel kalkınmayı açıklamada beşeri sermayenin ve yaratıcı sınıfin mesleğe dayalı ölçütünün kullanıldığı çalışmaların yanında beşeri sermayenin coğrafi dağıımını etkileyen faktörlerin belirlenmesine yönelik 3 farklı hipotez ortaya konulmuştur. Beşeri sermayenin bölgesel dağılımında birbirlerini tamamlayıcı bu hipotezler;

- Üniversitelerin beşeri sermaye yaratımındaki etkisi,

- Yaşamı kolaylaştırıcı hizmetlerin varlığının yüksek eğitimli ve yüksek nitelikli hanehalkını bölgede tutması ya da bölgeye çekmesindeki etkisi,

- Toleransın (hoşgörünün) ve farklılıklara açık olmanın yaşamı kolaylaştırmadaki etkisi üzerinde yoğunlaşmıştır.

Gelişmiş ülke ölçeğinde yapılan çalışmaların ardından gelişmekte olan ülkelerde önerilen yeni beşeri sermaye ölçütünün ve dağılımı etkileyen faktörlerin test edilebilmesine yönelik bu çalışma, Florida'nın (2002a, 2003) yaratıcı sınıf tanımlamasından yola çıkılarak Türkiye ölçeğinde gerçekleştirilmiştir. Çalışmanın birinci bölümünde, yaratıcı sınıf ile ekonomik gelişme arasındaki ilişki üzerinde yoğunlaşan teorik ve ampirik literatür özetlenmiştir. İkinci bölümde, yol analizi ve yapısal eşitlikler modeli kısaca tanıtılmış, Florida, Mellander ve Stolarick'in (2008) geliştirdiği tez referans alınarak oluşturulan ve çalışmada kullanılan model ve değişkenler açıklanmıştır. Takip eden bölümde, yapısal eşitlikler ve yol analizi modeli kullanılarak, modelde yer alan bağımsız değişkenlerin bölgesel ekonomik gelişme üzerinde dolaysız etkilerinin olup olmadığı araştırılmış ve coğrafi dağılımında olağanüstü farklılık sergileyen beşeri sermaye ve yaratıcı sınıfin bu farklı 
dağılımını belirleyebilecek faktörler tartışılarak analizden edilen sonuçlar sunulmuştur. Sonuç bölümünde ise elde edilen sonuçların bir değerlendirmesi yapılmıştır.

\section{Literatür}

\subsection{Ekonomik Gelişmişlik ve Beşeri Sermaye}

İnsanın fiziki sermaye gibi bir sermaye unsuru olduğu görüşü, II. Dünya Savaşı sonrası ülke ekonomileri arasındaki gelişmişlik farklııklarının ön plana çıkması ve kalkınma kuramındaki gelişmelere paralel olarak Ullman (1958), Schultz (1962), Becker (1962), Denison (1962), Harbison (1962), Bowman ve Myers (1967), Mincer (1970) gibi iktisatçıların katkısıyla kuramsal bir bütünlük kazanmıştır. iktisatçıların çalışmaları, beşeri sermayenin ekonomik hayattaki rolü üzerine odaklanmış ve beşeri sermayenin ekonomik hayatta etkin rol oynadığı ve rekabet üstünlüğünün bir unsuru olduğu tezi üzerinde yoğunlaşmıştı. 1960'lı yıllarda ekonomik büyümeye yönelik yapılan çalışmalarda büyümenin eğitim sayesindeki verimlilik artı̧ı ile de ilişkilendirilmesi teori ve uygulamada beşeri sermayeye olan ilgiyi artırmıştı (Kandemir, 2008). Böylece beşeri sermaye, neo-klasik büyüme teorisi doğrultusunda, "Beşeri Sermaye Teorisi" başlığı altında, kalkınma ekonomisi literatüründe yerini almıştır.

Beşeri sermaye ile ekonomik büyüme arasındaki teorik ilişkiler, içsel ve dışsal büyüme modelleri çerçevesinde ele alınmaktadır. İçsel büyüme modeli, büyümenin dinamiği olarak beşeri sermaye birikimini kabul etmekte ve yenilik süreci ile teknolojiye uyumda bu birikimin rolü üzerinde durmaktadır. Romer (1986, 1987, 1990), içsel büyüme modeli ile teknolojiyi beşeri sermaye, bilgi ve ekonomik büyüme ile ilişkilendirmiştir. Neoklasik çerçevede, buluş veya yenilik dışsal faktörler olmaktan çıkmış, kaynak kullanımı gerektiren aktivitelere dönüşmüştür. Lucas (1988) tarafindan geliştirilen içsel büyüme modeli ile de beşeri sermayenin getirilerinin ekonomik kalkınmadaki rolü daha iyi açıklanmaya çalışımıştır. Romer'ın çalışmalarını daha da geliştiren Lucas, beşeri sermayenin kümelenme etkisine vurgu yapmıştr. Beşeri sermaye ve bilgiyi lokalleştiren büyük şehirlerin bilgiyi yayarak ekonomik büyümenin motoru haline geldiğini savunur. Büyük şehirler bilgi transferinin maliyetini düşürerek, fikirlerin daha hızlı taşınmasını, dolayısıyla yeni fikirlerin daha hızlı yükselmesini sağlar.

Teknolojinin ekonomik büyüme üzerindeki etkisinden bahseden Solow (1956) ise, modelinde teknolojiyi dışsal bir değişken olarak ele alır. Bu nedenle teknoloji, sermaye ile işgücü arasındaki marjinal ikame oranından etkilenmez. Solow (1956), teknolojinin ekonomik büyüme üzerindeki etkisine dikkat çekerken, Mankiw, Romer ve Weil (1992), üretim fonksiyonuna dışsal bir değişken olarak beşeri sermayeyi de ekleyerek Solow modelini genişletmiştir. Daha sonra gerçekleştirilen ampirik çalışmalarda da beşeri sermayenin bölgesel ekonomik kalkınma ve büyüme üzerindeki etkisi doğrulanmıştır (Glaeser, Scheinkman ve Shleifer, 1995; Glaeser ve Saiz 2003; Glaeser 1998, 1999, 2000; Simon 1998).

Beşeri sermaye teorisi yetenek veya bilgi seviyesindeki yükselme ile birlikte ücretlerin de artacağını kabul eder (Becker 1964, 1993; Mincer 1974). Ücret seviyesi beşeri sermaye birikimine bağlıdır ve çalışanın marjinal verimliliğinin değerini belirler. Dolayısıyla, ücretler bölgesel emek arz ve talebi tarafindan belirlenir. Daha da önemlisi, çalışmanın karşılığı olan ücretler doğrudan bölgedeki işgücü verimliliği ile ilişkilidir.

Literatürde, bilginin aktarılması ve yayılması konusunda şehir ve bölgelerin üstlendiği role dikkat çeken çalışmalar da bulunmaktadır (Jacobs 1961, 1969). Şehirlerde ölçek ve farklılıklar büyüdükçe ekonomik aktörler arasındaki ilişkilerin de artacağı ve dolayısıyla yeni fikirlerin üretiminin ve inovasyonun da yükseleceği varsayılmaktadır. Andersson (1985a, 1985b), büyük kentlerin ekonomik kalkınmasında yaratıcılı̆ın rolünü araştrarak, bilgi, kültür, iletişim ve yaratıcılığın bölgesel zenginlik üzerindeki etkilerini vurgulamıştır. Ayrıca tolerans ya da hoşgörünün şehir ve bölgelerde yaratıcılığı harekete geçirdiğini de ileri sürmüştür.

Ülkeler genelinde, beşeri sermaye ile ekonomik büyüme arasındaki ilişkiyi onaylayan çok sayıda ampirik çalışma bulunmaktadır (Barro 1991; Rauch 1993; Simon ve Nardinelli 1996, Glaeser 2000). Glaeser, firmaların rekabet avantajı elde etmek amacıyla, girdi ya da müşterilerin çokça bulunduğu coğrafyalardan ziyade beşeri sermayenin daha fazla yoğunlaştı̆ı bölgelere yerleştiğine işaret eder. 
Literatür incelendiğinde, geçmişte yapılan çalışmaların pek çoğunda beşeri sermaye ve diğer faktörlerin bölgesel kalkınma üzerindeki direkt etkisinin tekli regresyon eşitlikleri ile tespit edilmeye çalışıldığı görülmektedir. Yakın dönemde ise bu tarz yaklaşımların yerine, beşeri sermayenin bölgesel dağılımını etkileyen faktörlerin de bölgesel kalkınma üzerindeki dolaylı etkisinin ölçülebildiği farklı modeller üzerinde durulduğu görülmektedir (Mellander ve Florida 2006; Florida vd., 2008). Kullanılan eşitlikler sistemi ile anahtar değişkenlerin birbirlerine olan direkt ve dolaylı etkilerinin beraberinde, bölgesel kalkınma üzerindeki ayrıştrıımış etkileri de ölçülebilmiştir.

\subsection{Ekonomik Gelişmişlik ve Yaratıcı Sınıf}

Ekonomi alanında yapılan çalışmalar beşeri sermayenin ekonomik kalkınma için büyük önem taşıdığı konusunda hemfikir iken, iki önemli konu halen tartı̧̧ımaktadır. Birincisi, beşeri sermayenin en iyi nasıl ölçülebileceği ve açıklanabileceğidir. Beşeri sermayenin geleneksel ölçüsü eğitimdeki başarıya dayalıdır ve genellikle üniversite ve üzeri eğitim almış olanların aktif nüfus içindeki payı olarak ifade edilmiştir. Ancak, eğitim oldukça geniş bir kavramdır. Ülkelerde ya da bölgelerdeki özellikli beşeri sermayenin ve yeteneğin tespit edilmesine imkân vermemektedir. Yapılan çalışmalar, eğitimin emeğin verimliliğini yükseltmede kullanılabilecek araçlardan sadece bir tanesi olduğunu gösterirken, yaratıcılık, zekâ, işi yaparak öğrenme, birikmiş tecrübe gibi diğer faktörlerin de eğitim gibi emeğin verimliliğini etkileyebileceğini öne sürmektedir (Smith, Carlsson ve Danielsson, 1984). Eğitim zımni olarak belli bir seviyede beceri geliştirir fakat bu becerilerin üretken işlere dönüştürülmesi gerekir. Bu nedenle yapılan iş ya da meslek, eğitimi yeteneğe ya da işgücü verimliliğine dönüştüren bir aracı mekanizmadır.

Son dönemde yapılan araştırmalar ise, insanların ne iş yaptıklarının, ne eğitimi aldıklarından daha önemli olduğunu ileri sürmektedir. Dolayısıyla alternatif olarak bilgiye dayanan veya yaratıcı mesleklerle ilişkilendirilen mesleğe-dayalı ölçütler ileri sürülmüştür (Florida 2002a; Markusen 2004, 2006). Hollanda, İsveç ve $A B D$ için yapılan çalışmalarda, bölgesel kalkınmayı açıklamada beşeri sermayenin mesleğe dayalı ölçütünün, geleneksel beşeri sermaye ölçütüne göre daha anlamlı olduğunu göstermiştir (Marlets ve Woerken 2004; Mellander ve Florida 2006; Florida vd. 2008).

ikinci tartışma konusu ise, beşeri sermaye ve yaratıcı sınıfin coğrafi dağılımını etkileyen faktörler hakkındadır. Gelişmiş ülkeler kategorisinde bulunan ABD'de yer alan bölgelerin son yıllarda, beşeri sermaye düzeyi bakımından birbirlerinden önemli derecede farklılaştı̆ı gözlenince (Berry ve Glaeser, 2005), literatürde bölgesel dağılımda farklılı̆a yol açan faktörlerin daha iyi anlaşılması gerektiğine dikkat çekilmiştir (Florida 2002a, 2002b, 2002c, 2005a, 2005b, 2006; Mellander ve Florida 2006).

Yeteneğin ekonomik kalkınma ile ilişkili olduğu ve bölgeler arasında dengesiz bir şekilde dağıldığı bilindiğine göre, bu dengesiz dağılıma sebep olan faktörlerin anlaşılması büyük önem taşımaktadır. Ekonomistlerin çoğu beşeri sermayeyi doğal kaynaklar gibi bulundukları yerde sabit ya da bahşedilmiş sermaye olarak kavramsallaştırırken; Florida, beşeri sermaye üretimini arttran ve bölgelere beşeri sermayeyi çeken faktörleri açıklamaya çalışarak, beşeri sermayenin aslında durağan, bölgeye bahşedilmiş bir birikim olmaktan ziyade bölgeler arasında hareket eden dinamik bir unsur olduğunu ifade etmiştir. Dolayısıyla aslında yanıt bekleyen soru, beşeri sermayenin akışkanlığını şekillendiren ve beşeri sermaye ile yaratıcı sınıfların dengesiz dağılımına sebep olan faktörlerin neler olduğudur.

Bu soruya literatürde üç farklı cevap verilmiştir: Birinci faktör, Glaeser, Kolko ve Saiz (2001) beşeri sermayenin kendi kendini artırdığı yaklaşımıdır. Başlangıçta beşeri sermaye yönünden avantajlı olan yerleşim yerleri bu avantajın üzerinden daha da yüksek büyüme ve kazanç elde etme eğilimindedir. Büyük araştrma üniversitelerinin mevcudiyetinin bu başlangıç ivmesinin yakalanması konusunda anahtar role sahip olduğu anlaşıımıştır. Ancak, eğitimin ve niteliğin dağııımı ile üniversitelerin dağılımı birbirleriyle tutarlı olmak zorunda değildir. Çok iyi üniversitelerin bulunduğu bazı bölgeler yeteneğin toplandığı yerler iken, diğerleri ağırlıkı olarak beşeri sermaye üreten fakat yükseköğrenimli insanları başka bölgelere transfer eden ihracatçılar gibi çalışabilir (Florida vd. 2006). Florida (2005b), eğitimin inovasyon ve ekonomik getiriler ile olan coğrafi ilişkisinin aynı bölgede uzun süre devam etmeyeceğini savunur. Bu sonuç yüksek nitelikli ve eğitimli kişilerin ülke içi ve dışındaki yüksek mobilitesinden kaynaklanmaktadır. Dolayısıyla bölgede eğitim sistemi ne kadar iyi 
olursa olsun, bölgede yetişen yüksek eğitimli ve nitelikli kişilerin orada tutulabileceğinin bir garantisi yoktur. Bu bağlamda üniversiteler, yüksek eğitimli ve nitelikli kişileri bölgeye çekebilmek ya da bölgede kalmalarına devam etmeleri için gerekli fakat tek başına yeterli olmayan bir faktör olarak değerlendirilebilir.

Beşeri sermaye ve yaratıcı sınıfin dağılımını etkileyen ikinci faktör olarak bölgedeki imkânlar ya da yaşamı kolaylaştıran ve daha kaliteli kılan faaliyetlerin varlığı üzerinde durulmaktadır. Roback (1982), yaşam kalitesini etkileyen imkânları da dâhil ederek neoklasik modeli genişletmeye çalışmıştır. Glaeser vd. (2001) restoran, tiyatro ve müzeler gibi kişisel hizmet sunan endüstriler ile müşterilerin yerelleşme eğiliminde olduklarını ve bu nedenle üreticinin coğrafi olarak tüketiciye yakın olmasını istediklerini tespit etmiştir. Bazı araştırmalarda ise hayat tarzının (eğlence, gece hayat, kültür gibi) önemine işaret edilmiştir (Lloyd ve Clark 2001; Florida, 2002a, 2002b, 2002c). Florida (2002c), çalışmasında sanatsal ve kültürel imkânların ölçüsü olarak bohem indeksini kullanarak, yetenek ve inovasyon arasındaki ilişkiye dikkat çekmiştir. Shapiro (2006) tarafindan yapılan bir başka çalışmada ise, bölgesel istihdamdaki yükselişin \% 60'ının üniversite mezunlarından kaynaklı bölgesel verimlilik artşından, geri kalanının da yaşam kalitesindeki artş̧tan kaynaklandığı anlaşılmıştır.

Beşeri sermayenin seviyesini ve coğrafi dağııımını etkileyen üçüncü bir faktör olarak tolerans ya da farklııklara karşı açık olma gösterilmiştir. Ottaviano ve Peri (2005), bireysel farklııkların bölgesel verimliliği artrabileceğine işaret etmişlerdir. Özellikle göçmenlerin aynı işi, farklılık gösteren niteliklerini kullanarak yapmaları nedeniyle yerli halkın tamamlayıcısı olabileceklerini savunurlar. Bazı yazarlar da toplumda eşcinsellere gösterilen hoşgörü ile küresel ekonomik faaliyetlere olumlu yaklaşımın ve uluslararası finansal getirilerin birbirleriyle olan bağlantısına dikkat çekmişlerdir (Noland, 2005). Eşcinsellere karşı hoşgörülü olmanın o toplumun genel tolerans seviyesinin en iyi göstergesi olduğunu ileri süren çalışmalar vardır (Inglehart ve Norris, 2003; Inglehart ve Welzel, 2005). Florida ve Gates (2001) tarafindan yapılan bir çalışmada da eşcinsel kişilerin bölgesel yoğunlaşması ile bölgesel kalkınma arasında pozitif yönlü bir ilişkiye rastlanmıştır. Bu nedenle pek çok çalışmada tolerans faktörü, sanatsal yeteneği olanların ve/veya eşcinsellerin bölgedeki yoğunluğu ile ölçülmüştür.

Farklııklara karşı toleranslı olmak dört farklı mekanizma sayesinde yerel kaynakların daha verimli ve etkin kullanımına sebep olur: Bohem ve eşcinsel nüfusun varlığı o bölgede beşeri sermaye için düşük giriş bariyerleri anlamına gelmektedir. Böyle yerleşim yerlerinin farklı ırk, etnikte ve gruplarda yer alan yetenekli insanları büyük oranda bölgeye çekme konusunda avantajlı oldukları düşünülmektedir. İkincisi, daha fazla bohem ve eşcinsel nüfus, sanatsal bilgi ağı sayesinde bilginin daha etkin bir şekilde yayılmasını sağlarken, beşeri sermayenin getirilerini de arttrarak ekonomik büyümenin motoru haline gelir (Florida vd, 2008). Kısaca, sanatçıların ve eşcinsel nüfusun artan oranda yoğunlaşması, beşeri sermayenin getirilerini artıran ve bilginin yayılmasını hızlandıran bölgesel bir mekanizmayı ifade etmektedir. Üçüncü mekanizmaya göre, sanatçı ve eşcinsel kesimin varlığı, açık görüşlülük, meritokratik olma, riski tolere edebilme ve kendini ifade etmeye yönelme gibi bölgeye özgü değerleri ifade etmesi bakımından önemlidir. Nitekim bu değerlerden bazıları ile ekonomik büyüme arasında pozitif ilişki tespit eden çalışmalar bulunmaktadır (Inglehart ve Norris, 2003; Inglehart ve Welzel, 2005). Dördüncüsü ise, sanatçı ve eşcinsel kesimin daha yoğun olduğu lokasyonlarda girişim faaliyetlerinin verimliliğinin yüksek olabileceğidir (Florida vd., 2008).

Üniversiteler, bölgenin sunduğu hizmetler ve tolerans, ekonomik kalkınma üzerinde direkt etkili olabilecekleri gibi, bölgenin yetenek düzeyini etkileyerek dolaylı yoldan da bölgesel kalkınmayı etkileyebilmektedir.

\subsection{Yaratıcı Sınıf Tanımlaması}

Literatürde yaratıı sınıf tanımlaması Richard Florida ile başlar. Florida (2002a), "Yaratıcı Sınıfin Yükselişi" adlı eserinde, yaratıcı sınıfta yer alan insanların kentsel ve bölgesel büyümede anahtar rol oynadığı savını ileri sürmektedir. Çünkü bölgesel ekonomik gelişme yaratıcı sermayenin getirilerinden kaynaklanırken, yaratıcı sermaye de yaratıcı sınıfin üretmesi ile başlar. Aslında bölgesel gelişmişlik farkını yaratan bölge nüfusunun yaratıcı olup olmamasıdır. Yaratıcı sınıfin büyük oranda bulunduğu bölgeler ekonomik olarak daha 
iyi performans sergilerler. Çünkü bu bölgelerde, daha fazla yenilik geliştirilir, girişimcilik daha yüksek orandadır Dolayısıyla, bu bölgelerin, yaratıcı firmaları kendilerine çekme yetenekleri yüksektir.

Florida, yaratıcı sınıf tanımlamasını nitelik düzeyine veya endüstrilere göre değil, mesleklere göre yapar. Ona göre yaratıcı sınıf, yaratıcı ve yenilikçi işlerde çalışan ve bu çalışmaları nedeniyle gelir elde eden kişilerden oluşur. Mesleğe ilişkin bilgiler, endüstriyel bağlantı ya da eğitim seviyesine nazaran kişilerin gerçekte ne iş yaptığına ilişkin daha iyi bilgi sağlayabilir (Markusen ve Barbour, 2007). Yaratıcı ve kültürel sektörler bazı özel niteliklere sahip olsalar da (Power ve Scott, 2004), yaratıcı sınıf sadece bu endüstrilerle sınıflandırmak doğru olmayabilir.

Florida sınıflandırmasında, yaratıcı sınıfi "çekirdek yaratıı" (core creative), "profesyonel yaratıcılar" (Creative professionals) ve "çalışan bohemler" (employed bohemians) olmak üzere üçe ayırmaktadır. Çekirdek yaratıcı sınıflandırmasında; bilim insanları, mühendisler, üniversite araştırmacıları, şair ve yazarlar, sanatçılar, aktörler, tasarımcılar, mimarlar, editörler, düşünce kuruluşu araştırmacıları ve analistler gibi yeni teknoloji, fikir ya da içerik üretebilen kişiler bulunmaktadır. İş yönetimi, finans, yargı, sağlık profesyonelleri ile ilgili yardımcı profesyoneller ise profesyonel yaratıcılar sınıfina girmektedir. Bohemler ise, kültürel ve sanatsal işlerle meşgul olanlardır. Aslında bohemlerin rolü iki yönlü olup, hem yaratıcı sınıfın bir parçasıdırlar hem de kent kültüründeki hoşgörü ya da toleransı yansıtırlar. Çekirdek yaratıcı ve profesyonel yaratıcıları bölgeye çekmede önemli rol oynarlar.

\subsection{Türkiye'de Yaratıcı Sınıf ve Bölgesel Ekonomik Gelişmişlik}

Türkçe literatür tarandığında henüz Türkiye'de tam anlamıyla yaratıcı meslek tanımlaması yapan, yaratıcı sınıf 81 il için belirleyip analiz eden, yaratıcı sınıfın dağııımı ile ilin ekonomik gelişmişliği arasındaki ilişkiyi açıklayan ve hangi faktörlerin yaratıcı sınıfin bölgede konumlanmasını tetiklediğini araştıran bir çalışma yapılmamıştır. Bu alanda yeterince araştırma yapılamamasının nedeni detaylı istihdam verisinin olmayışıdır. Örneğin, Türkiye İstatistik Kurumu tarafindan uygulanan Hanehalkı İşgücü Anketi'nde ISCO-08 meslek kodlarının 2 basamak yerine daha yüksek detayda ve il bazında toplanamaması, yaratıcı sınıfin tespitini zorlaştırmaktadır.

Türkiye'de günümüze kadar yapılan çalışmalar belirli endüstrilerin ve illerin ya da bölgelerin üzerine yoğunlaştğı ve daha çok, yaratıcı ve kültürel sektörlerin faaliyetlerini inceleyen araştırma raporları niteliğinde yayınlar olduğu görülmektedir. Bu araştrrmalar; İstanbul, Ankara ve İzmir olmak üzere, üç büyük ilde yaratıcı endüstrilerin durumunu ortaya koyan raporlardır (Aksoy ve Enlil, 2011; Güran ve Seçilmiş, 2013; IZKA, 2013).

Bunların dışında, Türk yaratıcı ekonomisini, film endüstrisi bağlamında analiz etmeye çalışan ve Antalya'yı film endüstrisi itibarıyla yaratıcı bir il olarak tanımlayan (Durmaz, Platt ve Yigitcanlar, 2010), kent yaratıcılığını indeks hesaplayarak ölçen ve İstanbul'un inovasyon dostu bir şehir olduğunu tespit eden (Çetindamar ve Günsel, 2012) ve kayıtdışılık, yetersiz alt-yapı gibi olumsuzlukların yaratıcı endüstrilerin maruz kaldığı başlıca engeller olduğunu ortaya koyan (Binark ve Bayraktutan, 2012) çalışmalar yapıımıştır.

Başka bir çalışmada ise, Türkiye'de yaratıcı ve kültürel sektörlerin kümelenme eğilimleri araştırılmış ve sonuç olarak yaratıcı sektörlerin ülke genelinde ekonomik katkısının düşük kaldığı tespit edilmiştir (Lazzeretti, Capone ve Seçilmiş, 2014). Söz konusu çalışma Türkiye geneli ile üç büyük ilimizi ele almıştır.

Son dönemde, Florida'nın yaratıcı sınıf tanımlamasından yola çıkan ve TUiK'in gerçekleştirdiği Hanehalkı İ̧gücü Anketi'ndeki iki haneli ISCO-88 ikili meslek kodlarını kullanarak, yenilikçi sınıf tanımlaması geliştiren ve bu sınıfın Türkiye ve bölgesel olarak çalışan nüfusun ne kadarını oluşturduğunu hesaplayarak, bu değerler üzerinden yenilikçi sınıf ile bölgesel ekonomik gelişme arasında bir ilişki olup olmadığını analiz eden bir başka çalışma daha yapılmıştı (Özen, 2014). 2011 yılı verilerinin kullanıldığı söz konusu çalışmada, Türkiye'de istihdamın \%13,7'sinin yenilikçi sınıfa ve \%4,8'inin de yapısal yenilikçi çekirdeğe dâhil olduğu sonucuna ulaşılmıştır. Düzey 2 sınıflandırmasına göre, bölgeler arasında yenilikçi sınıfa dair bir açık olduğu tespit edilmiştir. Ayrıca yenilikçi sınıf ve yapısal yenilikçi çekirdek ile bölgesel ekonomik gelişmişlik arasında pozitif bir ilişkiye rastlanmıştır. Bu çalışmada bahsedilen ilişki nedensellik değil korelasyondur. Özen'in (2014) 
çalışmasında, hangi faktörlerin yenilikçi sınıfın bölgede konumlanmasını tetiklediği konusu ise tartı̧̧ılmamıştır.

Seçilmiş (2015) tarafindan Türkiye odaklı yapılan bir diğer çalışmada ise temel düzeyde yaratıcı endüstrilerin coğrafi kümelenmesi araştrılmıştır. DCMS tarafindan önerilen yaratıcı endüstri ölçüm ve sınıflandırma yönteminin esas alındığı bu çalışmada ekonomik faaliyetlerin coğrafi kümelenmesi analiz edilmiştir.

\section{Model}

Şehirlerde bilgi, kültür, iletişim, hoşgörü ve yaratıcılık arttıkça, ekonomik gelişmişliğin artacağı ileri sürülmektedir. Ancak şehirlerarasında bu unsurların eşit dağılıma sahip olmaması, bölgesel farklılıkları beraberinde getirmektedir. Bu farklılıkların etkisi altında, yaratıcı sınıfin illerin ekonomik gelişmişliği üzerindeki etkisini belirlemeyi konu alan bu çalışma kapsamında, geliştirilen modelin genel yapısı, Şekil 1'de verilmiştir. Model üzerindeki oklar, anahtar değişkenler arasındaki varsayılan ilişkilerin yönünü göstermektedir.

Şekil 1. Bölgesel Kalkınma Yol Modeli



Model, beşeri sermaye ve yaratıcı sınıfin bölgesel ekonomik gelişmişlik üzerindeki etkisini ortaya koymayı amaçlarken üç farklı analizi yapmaya imkan sağlamaktadır. Illk olarak, eğitimle ilişkilendirilen beşeri sermayeye karşı mesleki ya da yaratıcı sınıfin bölgesel ekonomik gelişmişlik üzerinde daha etkili olup olmadığının analizine imkan vermesidir. İkincisi, teknolojinin ve yetenek faktörünün bölgesel kalkınma üzerindeki bağımsız etkilerini ortaya koymasıdır. Üçüncüsü ise, geleneksel anlamdaki beşeri sermayenin ve yaratıcı sınıfın coğrafi dağılımını etkilediği düşünülen birincil öneme sahip faktörlerin (tolerans (bohem), üniversite ve hizmet) yetenek değişkenleri üzerindeki etkisinin sınanmasına olanak vermesidir.

\subsection{Araşttrmada Kullanılan Değişkenler}

Bu çalışmada, bölgesel ekonomik gelişmişlik, teknoloji, yetenek, bohem, üniversite ve hizmet değişkenleri kullanılmıştır. Çalışmada kullanılan değişkenler, 2013 yılı için Türkiye'de, "istatistiki Bölge Birimleri Sınıflandırması"na göre tanımlanan Düzey 3 kapsamında ele alınan 81 ili kapsamaktadır. Tüm değişkenlere ilişkin tanımlayıcı istatistikler Tablo 1'de sunulmuştur.

Tablo 1. Değişkenler ve Değişkenlere Ait Tanımlayıcı İstatistikler

\begin{tabular}{|l|c|c|c|c|c|}
\hline & $\mathrm{N}$ & Ortalama & Standart sapma & Minimum & Maksimum \\
\hline Kazanç & 81 & 52,06 & 5,90 & 42,38 & 78,05 \\
\hline Üniversite & 81 & 0,05 & 0,02 & 0,02 & 0,11 \\
\hline Bohem & 81 & 0,01 & 0,00 & 0,00 & 0,02 \\
\hline Teknoloji & 81 & 1250,44 & 5668 & 6 & 50.251 \\
\hline Hizmet & 81 & 0,11 & 0,02 & 0,06 & 0,16 \\
\hline Yetenek: & & & & & \\
\hline Eğitim (Beşeri Sermaye) & 81 & 0,12 & 0,03 & 0,06 & 0,23 \\
\hline Yaratıcı Sınıf & 81 & 0,18 & 0,02 & 0,13 & 0,24 \\
\hline
\end{tabular}

Not: Değişkenler modelde In dönüşümleri yapıldıktan sonra kullanılmıştır. 


\section{Bölgesel Ekonomik Gelişmişlik Değişkeni}

Literatürde bölgesel ekonomik gelişmişlik değişkeni olarak Gayrisafi Katma Değer, ücret, istihdamdaki arţ̧̧, nüfus artş oranı gibi ölçütler kullanılmaktadır. Aslında bölgesel gelişmişlik ile ifade edilen, bölgenin genel gelişmişlik ve yaşam standardı düzeyidir (Florida vd., 2008). Bu nedenle ilde bireylerin ne kadar kazandığını ve ilin toplam gelirini bilmek önemli hale gelir. Birçok insanın gelir kaynağı işgücü piyasasında ücret karşılığı sunduğu emeğidir ve işgücü piyasasında değeri belirlenen ücret toplumda refah düzeyini belirlemektedir. Ücret çalışmanın karşılığıdır ve birçok ekonomist tarafindan bölgesel işgücü verimliliğinin iyi bir yakınsaması olarak önerilir. Toplam gelir ise sadece ücretleri içermez faiz ve sermayenin getirileri ile kendi hesabına çalışma sonucu elde edilen gelir, sosyal transferler gibi kazanılmamış gelirleri de içerir. Türkiye'de yakın dönemde il bazında ortalama gelir değerlerine ulaşmak mümkün olmadığından çalışma kapsamında, bölgesel kalkınma bağımlı değişkeni olarak il bazında Sosyal Güvenlik Kurumundan (SGK) elde edilen 2013 yılı zorunlu sigortalı çalışanların prime esas ortalama günlük kazanç verileri kullanılmıştır. Göstergenin çalışma hayatının önemli bir boyutunu oluşturan ve bireyin iyi yaşamının belirleyicilerinden olan kazançları temsil ettiği düşünülerek kullanııması amaçlanmıştr.

\section{Teknoloji Değişkeni}

Patentleri, teknolojik gelişmenin seyrini belirleyen bilimsel ve teknolojik faaliyetlerin bir çıktısı olarak algılamak mümkündür. Çoğu gelişmekte olan ülkeler ve hatta gelişmiş ülkeler için, bilimsel ve teknolojik faaliyet göstergelerinin eksikliği patent verilerinin kullanılmasını gerektirmektedir (Bozkurt, 2014). Bu çalışmada, Türk Patent Enstitüsü kaynaklarından elde edilmiş 2013 yılına ait tescil edilen patent, faydalı model ve marka toplamı, teknoloji değişkeni olarak kullanılmıştr.

\section{Yetenek Değişkeni}

Modelde eğitim düzeyi ve mesleğe (yapılan işe) göre oluşturulan iki ayrı yetenek değişkeni kullanılmıştr.

Beșeri Sermaye (Eğitim Düzeyine Göre Yetenek Değișkeni): il bazında yükseköğrenim sahibi kişilerin, 15-64 yaş arası nüfus olarak da ifade edilen aktif çalışan nüfustaki yüzdesi olarak ölçülmüştür. Veri, Türkiye İstatistik Kurumunun Adrese Dayalı Nüfus Kayıt Sistemi (ADNK) istatistiklerinden elde edilmiştir.

Mesleğe ya da Yapılan İșe Göre Yetenek Değişkeni: Çalışmada, Florida'nın yaratıcı sınıf tanımlaması referans alınarak yaratıcı meslek grupları oluşturulmuştur. İstihdam içinde yer alan bu gruplar, çekirdek yaratıcılar, profesyonel yaratıılar ve bohem yaratıcılar olarak tanımlanırken, üçünün toplamı "yaratıcı sınıf" olarak isimlendirilmiştir. Mesleki gruplandırma için işgücü piyasasında mevcut olan mesleklerin, Uluslararası Standart Meslek Sınıflandırma Sistemi (ISCO- International Standard Classification of Occupations)'nin 2008 versiyonuna göre sınıflandırıldığı üç basamaklı meslek kodları kullanılmıştır. Çalışmada kullandığımız yaratıcı mesleklerin ISCO 08'e göre düzenlenmiş gruplaması Ek 1'de verilmiştir.

Tüm yaratıcı sınıf değişkenleri, SGK 2013 yılı istihdam verilerinden derlenen her ildeki yaratıcı meslek sahibi kişi sayısının ilin aktif çalışan nüfusundaki payı olarak ölçülmüştür. Model, bu yetenek değişkenleri için ayrı ayrı çalıştırılmıştır.

\section{Bohem Değişkeni}

Türkiye'de il bazında hesaplanmış tolerans (hoşgörü) indeks değerleri ya da diğer gelişmiş ülke çalışmalarında kullanılan Openness Index, Gay index ve benzeri veriler mevcut değildir. Bu nedenle, SGK 2013 yılı verilerinden derlenen zorunlu sigortalı olarak çalışan bohem grubunda yer alan kişilerin ilin aktif çalışan nüfusu içindeki payı bohem değişkeni olarak ele alınmıştır.

\section{Üniversite değişkeni}

Literatürde öğrenci başına düşen öğretim elemanı sayısı, bu değişken için kullanılmıştır (YÖK, 2016). 


\section{Hizmet değişkeni}

Hizmet sektöründe faaliyet gösteren girişimlerin toplam girişimlerdeki payı olarak kullanılmıştı (TUIK, 2013).

\subsection{Araşttrmada Kullanılan İstatistiksel Yöntem}

Çalışmada, yol analizi ve yapısal eşitlik modeli kullanılmıştır. Bu tercihin ana nedeni, değişkenler arasındaki sebep-sonuç ilişkisinin ve sonucu etkileyen değişkenler arasındaki direkt ve dolaylı etkilerin eşanlı incelenmesi gereksinimidir. Yol Analizinde her bağımlı değişken ve her bir bağımsız değişken arasında birden fazla regresyon analizi yapılabilmektedir (Kaygısız vd., 2005). Yol Analizi'nde amaç, değişken grupları arasındaki nedensel ilişkilerin önemliliğini ve büyüklüğünü tahmin etmektir. Ancak değişkenler arasındaki ilişkinin analizinden önce teorik olarak bağımlı değişkenin bağımsız değişkenlerle bağlantısını bir diğer ifade ile değişkenler arasındaki olası ilişki örüntüsünü belirlemek gerekmektedir (Şimşek, 2007). Bu aşama literatürde Yapısal Eşitlik Modellemesi olarak ifade edilmektedir.

Modelde (Şekil 1) gösterilen ilişkiyi tanımlayan aşağıdaki eşitlikler 4 farklı yetenek tanımlaması için (eğitim, çekirdek yaratıcı sınıf, profesyonel yaratıcılar ve toplam yaratıcı sınıf) ayrı ayrı tahmin edilmiştir.

$$
\begin{aligned}
& \text { Ln Yetenek }=\beta \text { InBohem }+\beta \text { InÜniversite }+\beta \text { InHizmet } \\
& \text { Ln Teknoloji }=\beta \text { InBohem }+\beta \text { InHizmet }+\beta \text { InYetenek }
\end{aligned}
$$

Ln Bölgesel Gelişme $=\beta \operatorname{lnBohem}+\beta \ln Y$ etenek $+\beta \operatorname{lnTeknoloji}$

\section{Analiz Sonuçları}

Çalışmanın bu bölümünde ilk olarak, beşeri sermaye (eğitim), yaratıcı sınıf, teknoloji, ücretler ve nüfusun coğrafi dağılımına ilişkin bilgi verilerek ülkedeki genel tablo değerlendirilmiş olacaktır. Daha sonra anahtar değişkenler arasındaki ikili ilişkilerin analizi ile sonuçların değerlendirilmesine başlanacaktır. Son olarak modelin sonuçları değerlendirilecektir.

2013 yılı adrese dayalı nüfus kayıt sistemine (ADNKS) göre Türkiye'nin nüfusu toplam 76.667.864 kişi, çalışma çağındaki nüfus olarak tanımlanan $15-64$ yaş arası nüfus, toplam nüfusun yüzde 66 'sı oranındadır. Çalışabilecek durumdaki nüfus dilimi içinde bulunan ve belirli bir işi olan aktif nüfusun çalışma çağındaki nüfusa oranı ise yüzde $33^{\prime}$ dür. Aktif nüfusun yüzde 80'i 4/a (SSK), yüzde 9'u 4/b (BAĞKUR), yüzde 11'i ise 4/c (Emekli Sandığı) kapsamında istihdam edilmiştir. Çalışmada ISCO-08 kodlamasının kullanıldığı 4/a verileri ile ISCO-08 kodlaması dışında kalan $4 /$ b ve $4 /$ c verileri esas alınarak yaratıcı sınıf gruplaması yapılmıştır. Buna göre 2013 yılı Aralık ayı verilerine göre 4/a kapsamında istihdam edilen aktif nüfus sahip oldukları mesleklere göre ayrıştrılmış ve yüzde 14'ü profesyonel yaratıcı, yüzde 4'ü çekirdek yaratıcı, yüzde 2'si bohem olarak belirlenmiştir. 4/b kapsamında istihdam edilen aktif nüfusun yüzde 3'ü profesyonel yaratıcı, yüzde 1'i çekirdek yaratıcı, yüzde $1^{\prime} i$ bohem olarak gruplanmıştır. 4/c grubunda çalışanlar ise yüzde 17 profesyonel yaratıcı, yüzde 37 çekirdek yaratıcı, binde 4 bohem olarak gruplanmıştır. SGK geneli ele alındığında toplam istihdamın yüzde 13'ü profesyonel yaratıcı, yüzde 8'i çekirdek yaratıcı, yüzde 1'i bohem olarak gruplanmıştır. Bu verilere göre, Türkiye' de çalışma çağındaki nüfusun yaklaşık \% $7,3^{\prime}$ lük kısmı, zorunlu sigortalı olarak çalışan nüfusun ise yaklaşık \%22,4'lük kısmı yaratıcı sınıf kapsamında değerlendirilebilmektedir.

Türkiye geniş bir coğrafyaya ve birbirinden farklı özellikler taşıyan bölgelere sahiptir. Nüfus da ülkenin her bölgesine eşit dağılmamıştır. Kimi bölgelerde büyük bir yığılma görülürken, kimi geniş alanlarda da düşük bir nüfus yoğunluğu bulunmaktadır. Tablo 2 , çalışmada kullanılan anahtar değişkenlerin iller arasındaki eşitsiz dağııımına işaret etmesi bakımından önemlidir. İstanbul ülke nüfusunun yaklaşık yüzde 19'una sahip iken, kazancın yüzde 28 , beşeri sermayenin yüzde 23 , istihdamdaki yaratıcı sınıfin yüzde 29 , çekirdek yaratıcı sınıfin yüzde 21, profesyonel yaraticıların yüzde 32 ve istihdamdaki bohemlerin yaklaşık yüzde 42 'sine ve teknolojinin de yüzde 50'sine sahiptir. İlk dört büyük şehrimiz ülke nüfusunun yüzde 34'ünü oluştururken, 
kazançta yüzde 49 , teknolojide yüzde 68 , beşeri sermayenin yüzde 45 , yaratıcı sınıfin yüzde 50 , çekirdek yaratıcıların yüzde 43, profesyonel yaratıcıların yüzde 53 ve bohem yaratıcıların da yüzde 63'üne sahiptir.

Tablo 2. Anahtar Değişkenlerin Coğrafi Dağılımı

\begin{tabular}{|c|c|c|c|c|c|c|c|c|}
\hline İL & Kazanç & Nüfus & Teknoloji & $\begin{array}{c}\text { Beşeri } \\
\text { Sermaye }\end{array}$ & $\begin{array}{c}\text { Yaratıcı } \\
\text { Sınıf }\end{array}$ & $\begin{array}{l}\text { Çekirdek } \\
\text { Yaratıcılar }\end{array}$ & $\begin{array}{c}\text { Profesyonel } \\
\text { Yaratıcılar }\end{array}$ & $\begin{array}{l}\text { Bohem } \\
\text { Yaratıcılar }\end{array}$ \\
\hline İstanbul & 28,18 & 18,47 & 49,61 & 23,44 & 29,28 & 21,31 & 32,50 & 42,37 \\
\hline Ankara & 10,09 & 6,58 & 8,20 & 11,34 & 10,61 & 11,53 & 10,15 & 9,89 \\
\hline İzmir & 5,97 & 5,30 & 5,98 & 7,02 & 6,36 & 5,79 & 6,76 & 5,74 \\
\hline Bursa & 4,21 & 3,58 & 4,48 & 3,59 & 4,14 & 3,87 & 4,21 & 4,96 \\
\hline Kocaeli & 3,58 & 2,19 & 1,85 & 2,32 & 3,06 & 2,88 & 3,26 & 2,11 \\
\hline Antalya & 3,18 & 2,82 & 2,80 & 3,09 & 3,36 & 3,02 & 3,50 & 3,86 \\
\hline Adana & 2,15 & 2,80 & 1,69 & 2,55 & 2,34 & 2,67 & 2,23 & 1,56 \\
\hline Konya & 2,07 & 2,71 & 3,06 & 2,31 & 2,20 & 2,66 & 2,01 & 1,47 \\
\hline Manisa & 1,72 & 1,77 & 0,74 & 1,39 & 1,38 & 1,51 & 1,39 & 0,64 \\
\hline Mersin & 1,65 & 2,22 & 1,04 & 2,09 & 1,64 & 2,05 & 1,48 & 1,00 \\
\hline Toplam $(\mathrm{N}=10)$ & 62,82 & 48,44 & 79,47 & 59,14 & 64,38 & 57,28 & 67,49 & 73,61 \\
\hline Diğer Toplam ( $\mathrm{N}=71$ ) & 37,18 & 51,56 & 20,53 & 40,86 & 35,62 & 42,72 & 32,51 & 26,39 \\
\hline Toplam & 100,00 & 100,00 & 100,00 & 100,00 & 100,00 & 100,00 & 100,00 & 100,00 \\
\hline
\end{tabular}

Kaynak : SGK, TUiK ve Türk Patent Enstitüsü’nden elde edilen ilgili veriler kullanılarak yazarlar tarafından hesaplanmıştır.

Tablo 3. Anahtar Değişkenler için Korelasyon Matriksi

\begin{tabular}{|c|c|c|c|c|c|}
\hline & Kazanç & Eğitim & Bohem & $\begin{array}{l}\text { Çekirdek } \\
\text { Yaratıcı }\end{array}$ & $\begin{array}{c}\text { Profesyonel } \\
\text { Yaratıcı }\end{array}$ \\
\hline Kazanç & 1 & & & & \\
\hline $\begin{array}{l}\text { Eğitim } \\
\text { (Beşeri Sermaye) }\end{array}$ & $0,397 * *$ & 1 & & & \\
\hline Bohem & $0,353^{* *}$ & $0,447 * *$ & 1 & & \\
\hline Çekirdek Yaratıcı & 0,003 & $-0,245^{*}$ & $-0,190 *$ & 1 & \\
\hline Profesyonel Yaratıcı & $0,512 * *$ & $0,629 * *$ & $0,543 * *$ & $-0,136$ & 1 \\
\hline Yaratıcı Sınıf & $0,453^{*}$ & $0,397 * *$ & 0,455 & $0,514^{* *}$ & $0,770 * *$ \\
\hline
\end{tabular}

Tablo 3'de temel değişkenler arasındaki korelasyon katsayıları verilmiştir. Tablodan da anlaşıldığı üzere beşeri sermaye, yaratıcı sınıf, bohem ve profesyonel yaratıcı sınıf ile bölgesel gelişmişlik arasındaki korelasyon istatiksel olarak anlamlıdır. Geleneksel beşeri sermaye ölçütü olan Eğitim ile Kazanç arasındaki korelasyon katsayısı Toplam Yaratıı Sınıf ile ya da Profesyonel Yaratıcı Sınıf ile Kazanç arasındaki korelasyon katsayısından daha düşüktür. Çekirdek Yaratıcı Sınıf ile Kazanç arasındaki korelasyon ise istatistiksel olarak anlamlı değildir. Korelasyon matriksi analizine göre şimdiden yaratıcı sınıfin eğitime göre bölgesel ekonomik gelişmişlik üzerinde daha etkili olduğu söylenebilir.

\section{Yol Analizi ve Yapısal Eşitlikler Modelinin Sonuçları}

Sonuçların değerlendirilmesine yetenek değişkeninin yerine beşeri sermayenin geleneksel ölçütü olan yüksek eğitimin yer aldığı model ile başlanacak ve sırasıyla yetenek yerine yaratıcı sınıfin kullanıldığı diğer modelle devam edilecektir. Söz konusu modeller yeteneğe ilişkin farklı ölçümlerin teknoloji ve bölgesel ekonomik gelişmişlik üzerindeki etkisini araştırırken, üç anahtar faktörün yeteneğin cografi dağlımı üzerindeki etkilerini de incelemektedir.

Tablo 4 ve Tablo 5'de, bölgesel gelişme için uyum iyiliği ve yapısal eşitlik sonuçları rapor edilmiştir. Yetenek değişkeni için listelenen yol analizi şemasında standardize edilmiş $\beta$ katsayıları Şekil 2'de ayrıca 
verilmiştir. Bu katsayılar ilgili bağımsız değişkenin bağımlı değişkenle olan ilişkisindeki nispi öneminin belirlenmesinde kullanılabilmektedir.

Tablo 4. Modelin Anlamlılığına İlişkin İstatistikler

\begin{tabular}{|l|l|l|l|l|}
\hline & \multicolumn{2}{l|}{$\begin{array}{l}\text { Beşeri Sermaye } \\
\text { (Eğitim) }\end{array}$} & \multicolumn{2}{l|}{ Yaratıcı Sınıf } \\
\hline & Değer & Sonuç & Değer & Sonuç \\
\hline Chi-Square & 0,96 & İyi uyum & 0,40 & İyi uyum \\
\hline DF & 3 & & 3 & \\
\hline RMSEA & 0,000 & İyi uyum & 0,000 & İyi uyum \\
\hline NFI & 0,99 & İyi uyum & 0,99 & İyi uyum \\
\hline RFI & 0,96 & İyi uyum & 0,97 & İyi uyum \\
\hline AGFI & 0,97 & İyi uyum & 0,99 & İyi uyum \\
\hline
\end{tabular}

Tablo 5. Yapısal Eşitlik Modeli Sonuçları

\begin{tabular}{|l|c|c|c|c|c|c|}
\hline \multirow{2}{*}{ KAZANÇ } & \multicolumn{3}{|c|}{ Beşeri Sermaye (Eğitim) } & \multicolumn{3}{c|}{ Yaratıcı Sınıf } \\
\cline { 2 - 7 } & Yetenek & Teknoloji & Kazanç & Yetenek & Teknoloji & Kazanç \\
\hline Değişkenler & $(1)$ & $(2)$ & $(3)$ & $(1)$ & $(2)$ & $(3)$ \\
\hline Bohem & $0,52^{* *}$ & $0,28^{* *}$ & 0,20 & $0,42^{* *}$ & $0,42^{* *}$ & 0,19 \\
\hline Üniversite & $-0,15$ & & & $-0,13$ & & \\
\hline Hizmet & $0,24^{* *}$ & $-0,44^{* *}$ & & 0,03 & $-0,34^{* *}$ & \\
\hline Yetenek & & $0,44^{* *}$ & $0,26^{* *}$ & & $0,20^{* *}$ & $0,36^{* *}$ \\
\hline Teknoloji & & & 0,02 & & & 0,02 \\
\hline Gözlem Sayısı & 81 & 81 & 81 & 81 & 81 & 81 \\
\hline$R^{2}$ & 0,37 & 0,50 & 0,17 & 0,18 & 0,41 & 0,23 \\
\hline
\end{tabular}

*Standardize edilmiş path katsayılarının istatiksel olarak anlamlı olduğunu göstermektedir.

\section{Şekil 2. Beşeri Sermaye, Yaratıcı Sınıf ve Kazanç Değişkenleri İçin Yol Analizi}

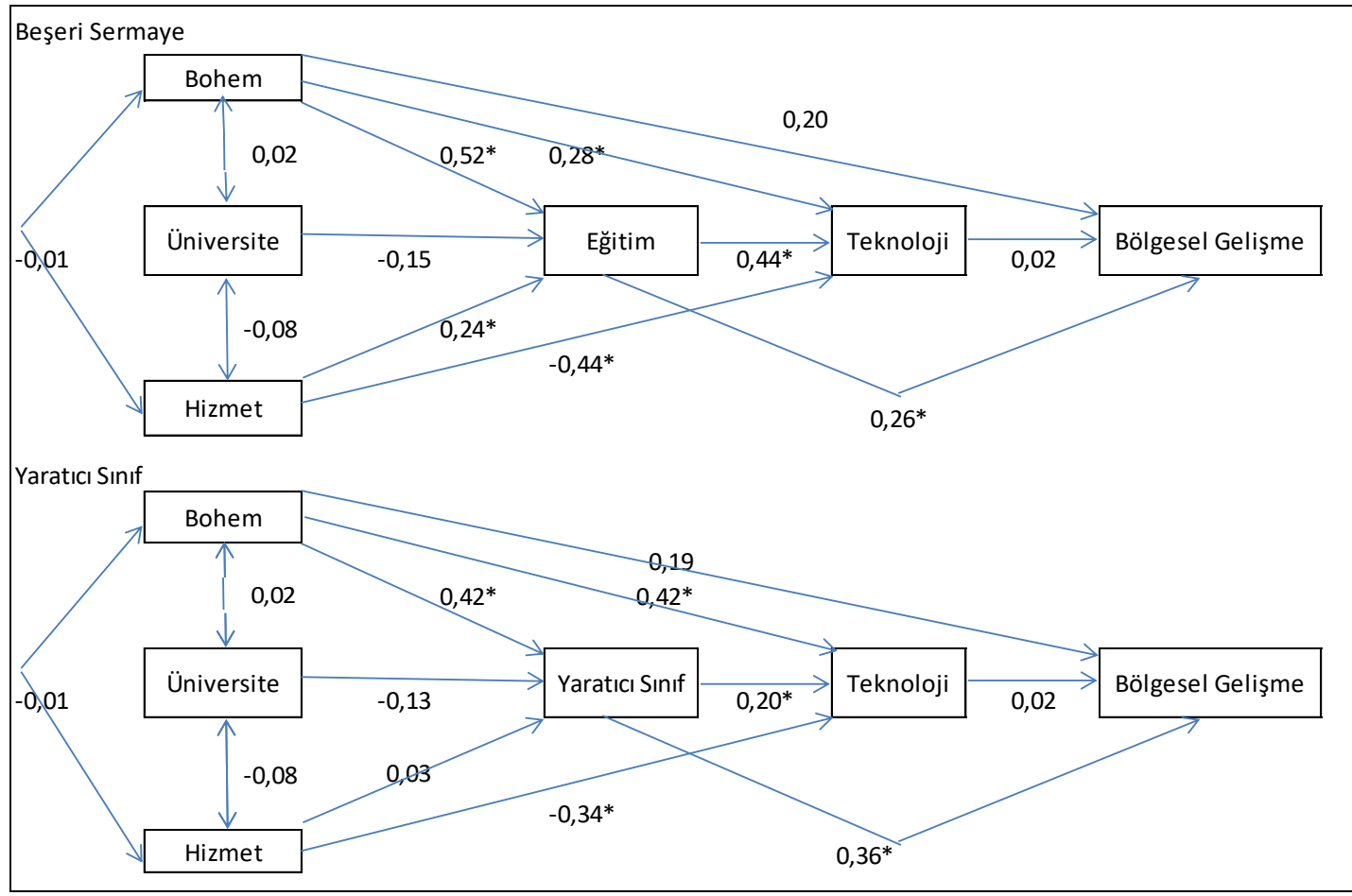

*path katsayılarının istatiksel olarak anlamlı olduğunu göstermektedir. 


\section{Beşeri Sermaye (Ĕgitim)}

Şekil 2, geleneksel beşeri sermayenin bölgesel ekonomik gelişmişlik üzerinde doğrudan etkili olduğunu göstermektedir. Path katsayısı pozitif $(0,26)$ ve istatistiksel olarak anlamlıdır. Teknoloji ile bölgesel ekonomik gelişmişlik arasındaki path katsayısı ise pozitif fakat istatistiksel olarak anlamlı değildir. Eğitim ile teknoloji arasındaki path katsayısı pozitif $(0,44)$ ve istatistiksel olarak anlamlı bulunmuştur.

Beşeri sermayenin dağılımını etkileyen faktörler incelendiğinde bohem ve hizmet değişkenleri, eğitim üzerinde pozitif ve anlamlı etkiye sahip olan değişkenlerken üniversite değişkeninin etkisi, istatistiksel olarak anlamlı bulunmamıştı. Bohem ve hizmet değişkenlerinin etkileri karşılaştıııldığında, bohemin etkisinin hizmetten daha yüksek olduğu gözlenmiştir. Eğitim ile birlikte kurulan bu modelde determinasyon katsayısı 0,37 olarak elde edilmiştir. Tablo 4'de gösterilen uyum iyiliği istatistikleri, modelin anlamlı olduğu sonucunu vermektedir.

\section{Yaraticı Sinif}

Şekil 2'de yaratıcı sınıf ve bölgesel gelişmişlik arasındaki path katsayısının pozitif ve istatistiksel olarak anlamlı olduğu gözlenmektedir. Yaratıcı sınıf ile teknoloji arasındaki ilişkinin path katsayısı da pozitif ve anlamlı iken teknoloji bölgesel gelişmişlikle ilişkilendirilememektedir. Yaratıcı sınıf, teknoloji ve bölgesel geliş̧işlik ile doğrudan ilişkilidir. Ayrıca yaratıcı sınıf ile bölgesel ekonomik gelişmişlik arasındaki path katsayısı (0.36), beşeri sermayeye göre (0.26) daha yüksektir.

Yaratıcı sınıfin dağılımı ile ilişkilendirilen faktörler incelendiğinde hizmet ve üniversite değişkenleri yaratıcı sınıf üzerinde anlamsız bir etkiye sahiptir. Bohemin etkisi ise pozitif ve istatistiksel olarak anlamlıdır $(0,42)$. Toplam yaratıcı sınıf ile kurulan bu modelde determinasyon katsayısı ise 0,18 olarak elde edilmiştir. Tablo 4'de raporlanmış olan uyum iyiliği istatistikleri, bu modelin anlamlı olduğu sonucunu vermektedir.

\section{Sonuç}

Türkiye ekonomisinin yaşadığı en temel sorunların başında bölgelerarası gelişmişlik farkları gelmektedir. Bölgesel gelişmişlik farklılıkları, coğrafi koşullar, uygulanan kalkınma modelleri, alt yapı kapasitesi, pazara ve girdi piyasalarına yakınlık gibi fiziksel sermaye faktörleri ve yetişmiş insan gücü olarak ifade edilen beşeri sermaye faktörü gibi birçok parametrenin etkisi altındadır. Faktörlerin etki derecesine göre, bazı bölgeler ülkenin diğer bölgeleri ile uyum sağlayamamakta gelişmişlik farklılıkları büyümektedir.

Bu çalışmada, gelişmiş ülke ölçeğinde yapılan çalışmaların ardından ekonomik gelişmişliği etkilediği düşünülen ve yeni beşeri sermaye ölçütü olarak ifade edilen yaratıcı sınıfin, geleneksel beşeri sermaye ölçütü olan yüksek eğitimin ve teknolojinin bölgesel ekonomik gelişmişlik üzerindeki etkisi Türkiye ölçeğinde test edilmeye çalışılmıştır. Florida'nın yaratıcı sınıf tanımlamasından ve geliştirdiği model üzerinden yola çıkan bu çalışmada, Yapısal Eşitlik Modeli ve Yol Analizi ile illerin gelişmişlik düzeyi üzerinde etkili olduğu düşünülen faktörlerin hangilerinin anlamlı olduğu sınanmış, anlamlı bulunan değişkenlerin etkileri ise direkt ve dolaylı etkiler olarak ayrı ayrı ifade edilmiştir. Ayrıca 81 ildeki coğrafi dağılımında olağanüstü farklılık sergileyen beşeri sermaye ve yaratıcı sınıfın bu farklı dağılımını belirleyebilecek faktörler de tartş̧ımıştır.

Çalışmada kullanılan model, yetenek, teknoloji ve bohem faktörlerinin bölgesel ekonomik gelişmişlik üzerindeki bireysel ve birleşik etkilerini incelemek üzere kullanılan aşamalı bir modeldir. Birinci aşamada, bohemler, üniversite ve yaşamı kolaylaştıran hizmetlerin varlığı gibi faktörler yeteneğin coğrafi dağılımını belirlemektedir. íkinci aşamada, yeteneğin dağılımı teknolojiyi etkilerken; üçüncü aşamada teknoloji, yetenek ve bohemler beraberce bölgesel kazancı etkilemektedir. Aşamalı model yapısı itibariyle yol analizi ve yapısal eşitlik modelleri, bahsi geçen faktörler arasındaki direkt ve dolaylı ilişkileri ayırt edebilme firsatı vermektedir.

Çalışma ile belirlenen amaçlara ulaşmada öncelikle Türkiye'de 81 ilde zorunlu sigortalı olarak çalışan nüfusun ne kadarının yaratıcı sınıf oluşturduğu belirlenmeye çalışıımıştır. Yaratıcı sınıfin belirlenmesinin ardından beşeri sermayenin, yaratıcı sınıfın ve teknolojinin bölgesel ekonomik gelişme üzerinde bağımsız etkilerinin olup olmadığı sınanmıştır. Bu aşamada veri eksikliğinden dolayı bağımlı değişken olarak bölgesel ekonomik gelişmişliği temsil ettiği düşünülen, bölgesel işgücü verimliliğini gösteren ortalama kazanç 
değişkeni esas alınmıştır. Yol analizi ve yapısal eşitlikler modelleri kullanılarak beşeri sermaye, yaratıcı sınıf ve bölgesel ücretler arasındaki direkt ve dolaylı ilişkiler incelenmiştir.

Türkiye'de 81 il için yapılan araştrrmanın sonucunda, bulgular iki önemli sonuca işaret etmektedir. Birincisi, yaratıcı sınıf bölgesel işgücü verimliliğini beşeri sermayeye göre daha fazla etkilemekte ve bölgesel gelişmeyi daha iyi açıklayan bir araç niteliği göstermektedir. Ancak bu yeni ölçütün bölgesel kalkınmaya yönelik çalışmalarda daha etkin kullanılabilmesi için iş yerlerinden toplanılan istihdam verileri üzerinde SGK denetiminin daha aktif hale getirilmesi ve SGK kapsamında 4/a, 4/b ve 4/c için ortak meslek kodlamalarının geliştirilmesine çalışılmalıdır.

İkincisi, hoşgörü ve farklılıklara karşı toleranslı olmayı temsil ettiğini düşündüğümüz bohem yaratıcıların bölgesel işgücü verimliliği ve diğer değişkenlerle olan güçlü ilişkisidir. Kültürel ve sanatsal olarak daha yaratıcı insanların (bohem yaratıcılar) yoğunlukta bulunduğu bölgeler toleransı ve farklılıklara açık olmayı temsil etmektedir. Bölgede kültürel ekonominin büyüklüğü daha fazla mal ve hizmet üretimine yol açarken, diğer yaratıı kişileri de bölgeye çekmektedir.

Yeteneğin bölgelerarası dağılımında, üniversitelerin ve bölgede yaşamı kolaylaştıran hizmetlerin değil, bohem grubun varlığının etkili olduğu gözlenmiştir. Bölgede yaşamı kolaylaştıran hizmetlerin varlığı sadece geleneksel beşeri sermaye değişkeninin dağılımını pozitif yönde etkilerken diğer yetenek değişkenleri üzerindeki etkisi istatiksel olarak anlamsızdır. Türkiye' de üniversite değişkeni olarak kullanılan öğrenci başına düşen öğretim elemanı çok düşük çıkmaktadır. Öğretim elemanlarının öğrencilere göre sayıca çok düşük olması ve üniversitelerin çoğunun araştırma üniversitesi olmayışı, üniversite değişkeninin yeteneğin coğrafi dağılımı üzerindeki etkisinin düşük ve anlamsız olmasının nedenlerinden biri olabilir.

Bu çalışmada, Türkiye'nin ekonomik kalkınmasına yüksek katkı sağlayabilecek olan yaratıcı sınıfin istihdamını ve bölgesel dağılımını etkileyebilecek faktörler, Florida'nın hipotezleri kapsamında incelenmiştir. Sonuç olarak, Florida'nın yüksek düzeydeki yaratıcılı̆ın bölgesel ekonomik gelişmeyi teşvik ettiği, toplam yaratıcı sınıfın illerin ekonomik gelişmişliğini açıklamada eğitim düzeyine göre daha başarılı olduğu tezleri Türkiye örneğinde doğrulanırken, yaratıcı sınıfin coğrafi dağıımını etkileyen faktörlere ilişkin hipotezi doğrulanamamıştır.

Çalışmanın bulgularının, genellikle bölgesel gelişmişlikle ilişkilendirilmeyen sanat ve kültür alanındaki mesleklerin bu süreçte doğrudan ve oldukça önemli bir rol oynadığına işaret etmesi ilgi çekicidir. Bu sonuçlar göz önünde bulundurulduğunda, araştırmanın Türkiye ve benzeri gelişmekte olan ülkelerde, şehirlerarasındaki gelişmişlik farkını açıklama konusunda ilgililere farklı bir açıdan ışık tutabileceği düşünülmektedir. Hangi tür politikaların yaratıcı sınıfın bir bölgede konumlanmasını teşvik edeceği konusunun incelenmesi büyük önem taşımaktadır. Çalışmanın yaratıcı sınıf bölgeye çeken faktörlere yönelik daha ayrıntılı çalışmalara zemin olacağı ve bölgelerin kalkınma politikalarının geliştirilmesinde farklı bir bakış açısı kazandıracağı düşünülmektedir.

\section{Kaynaklar}

Aksoy, A., \& Enlil, Z. (2011). Kültür ekonomisi envanteri. istanbul 2010 (ISBN: 9786-0539-920-35). İstanbul: İstanbul Bilgi Üniversitesi Yayınları.

Andersson, A. E. (1985a). Creativity and regional development. Papers of the Regional Science Association, 56, 5-20.

Andersson, A. E. (1985b). Creativity-The future of metropolitan regions. Stockholm: Prisma.

Barro, R. J. (1991). Economic growth in a section of countries. Ouarterly Journal of Economics, 106(2), 407443.

Becker, G. (1962). Investment in human capital: A theoretical analysis. Journal of Political Economy, Vol. 70, No. 5, Part 2: Investment in Human Beings, 9-49. 
Becker, G. (1964). Human capital. New York: Columbia University Press for the National Bureau of Economic Research.

Becker, G. (1993). A Theoretical and empirical analysis, with special reference to education. Chicago, The University Press of Chicago.

Berry, C. R., \& Glaeser, E. L. (2005). The divergence of human capital levels across cities. NBER Working Paper No. 11617.

Binark, M., \& Bayraktutan, G. (2012). A critical interpretation of a new "creative industry" in Turkey: Game studios and the production of a value chain, J. Fromme ve A. Unger (der.), Computer Games and New Media Cultures içinde, Netherlands: Springer, 371-391.

Bozkurt, K. (2014). Patent verileri ve teknolojik sınıflama sistemleri. Adnan Menderes Üniversitesi Sosyal Bilimler Enstitüsü Dergisi, 1(1) 1, 65-80.

Bowman M. J., \& Myers R.G. (1967). Schooling, experience, and gains and losses in human capital through migration. Journal of the American Statistical Association, Volume 62, Issue 319, 875-898.

Çetindamar, D., \& Günsel, A. (2012). Measuring the creativity of a city: A proposal and an application. European Planning Studies, 20(8), 1301-1318.

Denison, E. F. (1962). Education, economic growth, and gaps in information. The Journal of Political Economy, Vol. LXX, No. 5, Part 2. University of Chicago Press, 124-128.

Durmaz, B., Platt, S., \& Yigitcanlar, T. (2010). Creativity, culture tourism and place-making: Istanbul and London film industries. International Journal of Culture, Tourism and Hospitality Research, 4(3), 198213.

Eşiyok, B. A., \& Sekmen F. (2012). Türkiye ekonomisinde bölgesel gelişmişlik farklııkları, Doğu Anadolu'nun bölgesel gelişmedeki yeri ve çözüm önerileri. Ankara: Türkiye Kalkınma Bankası A.Ş.

Florida, R., \& Gates, G. (2001). Technology and tolerance. The importance of diversity to high-technology growth, Washington D.C.: Brookings Institute.

Florida, R. (2002a). The rise of the creative class. New York: Basic Books.

Florida, R. (2002b). The economic geography of talent. Annals of the Association of American Geographers, 92(4): 743-755.

Florida, R. (2002c). Bohemia and economic geography. Journal of Economic Geography, 2: 55-71.

Florida, R. (2003). Entrepreneurship, creativity, and regional economic growth. In: The emergence of entrepreneurship policy: governance, starts-ups, and growth in the US knowledge economy, ed. David M Hart. Cambridge, UK: Cambridge University Press.

Florida, R. (2005a). The flight of the creative class. New York, NY: HarperCollins.

Florida, R. (2005b). Cities and the creative class. New York: Routledge.

Florida, R., Gates, G., Knudsen, B., \& Stolarick, K. (2006). The university and the creative economy.

http://www.creativeclass.org/rfcgdb/articles/Unıversity\%20For\%20City\%20and\%20Community\%204.pdf (Erişim Tarihi, 21 Temmuz 2015).

Florida, R., Mellander, C., \& Stolarick, K. (2008). Inside the black box of regional development. Journal of Economic Geography, 8, 615-649.

Florida, R. (2006). Where the brains are. Atlantic Monthly, 298(3), 34-36.

http://www.theatlantic.com/magazine/archive/2006/10/where-the-brains-are/305202 (Erişim Tarihi, 21 Temmuz 2015).

Glaeser, E. L. (1999). Learning in cities. Journal of Urban Economics, 46, 254-277.

Glaeser, E. L. (2000). The new economics of urban and regional growth. In The Oxford handbook of economic geography, ed Gordon, C., Meric, G., Feldman, M. 83-98, Oxford: Oxford University Press.

Glaeser, E., \& Mare, D. (2001). Cities and skills. Journal of Labor Economics, 19(2), 316-42.

Glaeser, E. L., Kolko, J., \& Saiz, A. (2001). Consumer city. Journal of Economic Geography, 1, 27-50. 
Glaeser, E. L., \& Saiz, A. (2003). The rise of the skilled city. NBER Working papers no 10191, National Bureau of Economic Research Inc.

Glaeser, E. L. (1998). Are cities dying? Journal of Economic Perspectives, 12:139-160.

Glaeser, E., Scheinkman, J.A., \& Shleifer, A. (1995). Economic growth in a cross-section of cities. Journal of Monetary Economics, 36(1), 117-43.

Güran, M.C. \& Seçilmiş, i.E. (2013). Ankara kültür ekonomisi: Sektörel büyüklüklerin değerlendirilmesi. Kültür Mirası ve Kültür Envanteri Projesi.

http://www.envanter.gov.tr/files/kultur-ekonomisi (Erişim Tarihi, 21 Temmuz 2015).

Harbison, F. H. (1962). Human resources development planning in modernising economies. International Labour Review, 435-458.

Inglehart, R., \& Baker, W. (2000). Modernization, cultural change and the persistence of traditional values. American Sociological Review, 65:19-51

Inglehart, R., \& Norris, P. (2003). Rising tide. New York and Cambridge: Cambridge University Press.

Inglehart, R., \& Weltel, C. (2005). Modernization, cultural change and democracy. New York and Cambridge: Cambridge University Press.

IZKA-İzmir Kalkınma Ajansı (2013). İzmir kültür stratejisi. İzmir 2012 Kültür Ekonomisi, Kültür Altyapısı Envanteri ve İzmir Kültür Ekonomisi Gelişme Stratejisi Projesi.

http://izka.org.tr/files/planlama/2_bolge_plani_dokumanlari/ 2014-2023/izmir_kultur_

stratejisi (Erişim Tarihi, 21 Temmuz 2015).

Jacobs, J. (1961). The death and life of great American cities. New York:Random House.

Jacobs, J. (1969). The economies of cities. New York: Random House.

Kandemir, T. (2008). Entelektüel sermaye kavramı ve tarihsel gelişimi. Rıza Aşıkoğlu vd (Ed.), Entelektüel Sermaye içinde (16-29). Ankara: Gazi Kitabevi.

Kaygısız, Z., Saraçlı S., \& Dokuzlar K. U. (2005). illerin gelişmişlik düzeyini etkileyen faktörlerin path analizi ve kümeleme analizi ile incelenmesi. VII. Uluslararası Ekonometri ve İstatistik Sempozyumu, İstanbul Üniversitesi İktisat Fakültesi, Ekonometri Bölümü, İstanbul.

Lazzeretti, L., Capone, F., \& Seçilmiş, İ.E. (2014). Türkiye'de yaratıcı ve kültürel sektörlerin yapısı. Maliye Dergisi, 166, Ocak-Haziran.

Lloyd, R., \& Clark, T. N. (2001). The city as an entertainment machine. K. Fox Gotham (ed) Research in Urban Sociology, Critical Perspectives on Urban Redevelopment (357-378). 6. Oxford: JAI/Elsevier.

Lucas, R. (1988). On the mechanics of economic development. Journal of Monetary Economics, 22: 3-42.

Mankiw, N. G., Romer, D, \& Weil, D (1992). A contribution to the empirics of economic growth. Quarterly Journal of Economics, 152: 407-37.

Markusen, A. (2006). Urban development and the politics of a creative class: Evidence from a study of artists. Environment and Planning A, 38, 1921-1940.

Markusen, A. (2004). Targeting occupations in regional and community economic development. Journal of the American Planning Association, 70(3), 253-268.

Markusen, A., \& Barbour, E. (2007). Regional occupational and industrial structure: Does one imply the other? International Regional Science Review, 30 (1), 72-90.

Marlet, G., \& Van Woerkens, C. (2007). The Dutch creative class and how it fosters urban employment growth. Urban Studies, 44, 2605-2626.

Mellander, C., \& Florida, R. (2006). Human capital or creative class-explaining regional development in Sweden. KTH/CESIS Working Paper Series in Economics and Institutions of Innovation.

Mincer, J. (1970). The distribution of labor incomes: A survey with special reference to the human capital approach. Journal of Economic Literature, Vol. 8, No. 1, 1-26. 
Mincer J. (1974). Schooling, experience and earnings. NewYork:Columbia University Press for the National Bureau of Economic Research.

Noland, M. (2005). Popular attitudes, globalization and risk. International Finance, 8(2): 199-229.

Ottaviano, G. I. P., \& Peri, G. (2005). Cities and culture. Journal of Urban Economics, 58: 304-337.

Özen, E.N. (2014). Türkiye'nin yenilikçi sınıfi-1: Yenilikçi sınıf ve bölgesel gelişme ile ilişkisi. Türkiye Ekonomi Politikaları Araştırmaları Vakfi. http://www.tepav.org.tr/upload/files/1394361997-4 (Erişim Tarihi, 21 Temmuz 2015).

Power, D., \& Scott, A. (2004). Cultural industries and the production of culture. London: Routledge.

Rauch, J. (1993). Productivity gains from geographic concentration of human capital: Evidence from the cities. Journal of Urban Economics, 34,380-400.

Roback, J. (1982). Wages, rents, and the quality of life. The Journal of Political Economy, 90(6), 1257-1278.

Romer, P. M. (1986). Increasing returns and long-run growth. Journal of Political Economy, 90 (October), 1002-37.

Romer, P. M. (1987). Crazy explanations of the productivity slowdown. NBER Macroeconomics Annual, 2, 163-202.

Romer, P. M. (1990). Endogenous technical change. Journal of Political Economy, 98(5), 71-102.

Schultz, T. W. (1962). Investment in human capital in poor countries. Paul D. Zook (ed) in Foreign Trade and Human Capital (3-6). Dallas: Southern Methodist University Press.

Seçilmiş, E. (2015). Türkiye'de yaratıcı endüstrilerin kümelenmesi. Ege Akademik Bakış, 15(1), 9-18. http://www.onlinedergi.com/makaledosyaları/51/pdf2015_1_2.pdf (Erişim Tarihi, 21 Temmuz 2016).

Shapiro, J. M. (2006). Smart cities: Quality of life, productivity, and the growth effects of human capital. The Review of Economics and Statistics, 88(2), 324-335.

Simon. C. (1998). Human capital and metropolitan employment growth. Journal of Urban Economics, 43:22343.

Simon, C., \& Nardinelli, C. (1996). The talk of the town: Human capital, information and the growth of English cities. 1861-1961. Explorations in Economic History, 33(3), 384-413.

Smith, G., Carlsson, I., \& Danielsson, A. (1984) Experimental examinations of creativity. Lund University.

Solow, R. (1956). A contribution to the theory of economic growth. Quarterly Journal of Economics, 70, 6594.

Şimşek, Ö. F. (2007). Yapısal eşitlik modellemesine giriş (Temel ilkeler ve LISREL uygulamaları). Ankara: Ekinoks.

Tansel, A. (2012). 2050’ye doğru nüfusbilim ve yönetim işgücü piyasasına bakış. Yayın No: T/2012-11/536. İstanbul: TÜSIAD.

Ullman, E. L. (1958). Regional development and the geography of concentration. Papers and proceedings of the Regional Science Association, 4: 179-98.

UNCTAD, Creative Economy Report (2008). http://www.unctad.org (Erişim Tarihi, 03 Şubat 2016).

UNCTAD, Creative Economy Report (2010). http://www.unctad.org (Erişim Tarihi, 03 Şubat 2016).

II Bazında İstihdam Verileri, 03.12.2015. Ankara: Sosyal Güvenlik Kurumu Başkanlığı.

http://www.tpe.gov.tr/TurkPatentEnstitusu/statistics (Erişim Tarihi, 21 Temmuz 2015).

http://www.sgk.gov.tr/wps/portal/tr/kurumsal/istatistikler (Erişim Tarihi, 15 Haziran 2015).

https://istatistik.yok.gov.tr (Erişim Tarihi, 21 Temmuz 2015).

http://www.tuik.gov.tr/ilGostergeleri/index.html (Erişim Tarihi, 03 Şubat 2016).

http://www.tuik.gov.tr/PreTablo.do?alt_id=1059 (Erişim Tarihi, 21 Temmuz 2015). 


\section{Ekler}

\section{Ek 1: Yaratıcı Meslek Gruplandırması}

\begin{tabular}{|c|c|}
\hline Yaratıcı Meslek Grupları & Meslekler (ISCO-08) \\
\hline Çekirdek Yaratıcılar & $\begin{array}{l}\text { Fizik ve yer bilimleri ile ilgili profesyonel meslek mensupları (211), Matematikçiler, istatistikçiler ve } \\
\text { aktüerler } \\
\text { (212), Yaşam bilimleri ile ilgili profesyonel meslek mensupları (213), Mühendislik ile ilgili } \\
\text { profesyonel meslek mensupları (214), Elektroteknoloji mühendisleri (215), Mimarlar, planlamacılar, } \\
\text { harita mühendisleri ve tasarımcılar (Tasarımcılar hariç) (216), Tıp doktorları (221), Veterinerler } \\
\text { (225), Diğer sağlık profesyonelleri (226), Üniversite ve yükseköğretim öğretim elemanları (231), } \\
\text { Mesleki eğitim öğretmenleri (232), Ortaöğretim (ortaokul ve lise) öğretmenleri (233), Illkokul ve okul } \\
\text { öncesi öğretmenleri (234), Eğitim ile ilgili diğer profesyonel meslek mensupları (235), Yazılım ve } \\
\text { uygulama geliştiricileri ve analistleri (251), Veri tabanı ve bilgisayar ağları ile ilgili profesyonel meslek } \\
\text { mensupları (252), Kütüphaneciler, arşivciler ve küratörler (262), Sosyal ve din ile ilgili profesyonel } \\
\text { meslek mensupları (din profesyonelleri hariç) (263), Filolog, Mütercim, Tercüman, Seslendirme } \\
\text { Çevirmeni,Iş̧aret Dili Çevirmeni (2643), Tütün Teknolojisi Mühendisi (7516.13) }\end{array}$ \\
\hline Profesyonel Yaratıcılar & 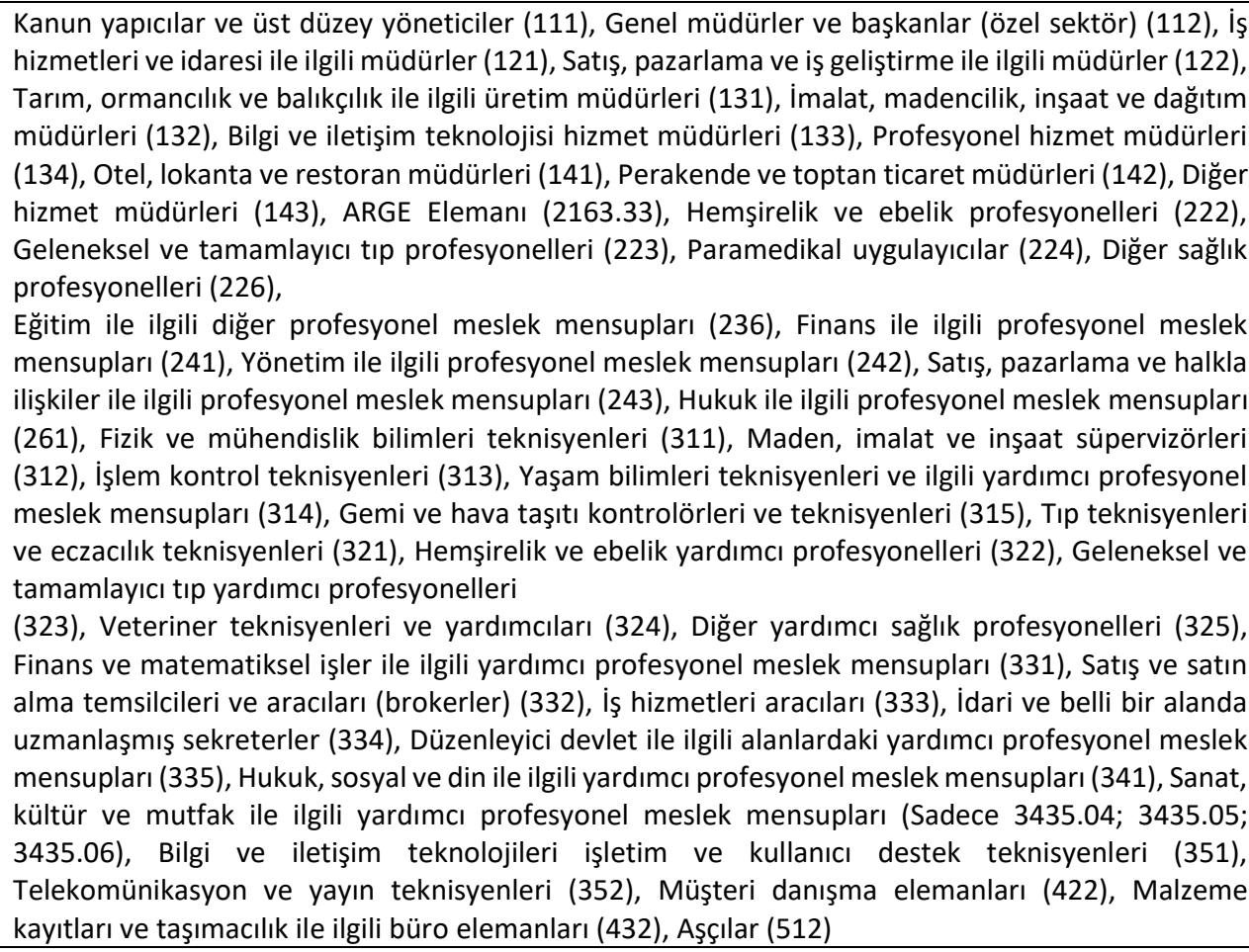 \\
\hline İstihdamdaki Bohemler & $\begin{array}{l}\text { Tasarımcılar,Stilistler ve Dekoratörler, Grafikerler (2163, 2166), Usta Öğreticiler }(2350,2360) \text {, } \\
\text { Yazarlar, gazete yazarları ve diğer yazarlar (2641;2642;2643), Yaratıcı sanatçılar ve sahne sanatçıları: } \\
\text { Heykeltraşlar, ressamlar ve ilgili sanatçılar, besteciler, müzisyenler, şarkıcılar, koreograflar, } \\
\text { dansçılar, film, sahne vb. aktörler ve yönetmenler (265), Atletler, sporcular ve ilgili meslek } \\
\text { mensupları (342), Sanat, kültür ile ilgili yardımcı profesyonel meslek mensupları (3431; } \\
\text { 3432;3433;3434;3445), } \\
\text { Telekomünikasyon ve yayın teknisyenleri (ses ve görüntü kaydeden donanım operatörleri, 3521), } \\
\text { Turist Rehberleri (5113.02;5113.03), Sahne ve stüdyo makyözleri, Baş perukçular (Sahne-Stüdyo) } \\
\text { (5141.03;5142.04), Mankenler ve Modeller (5241), Sahne ve stüdyo marangozları, Sahne } \\
\text { aksesuarcısı, Butaforcu (Sahne) (7115), El sanatları çalışanları; Müzik aleti yapımcıları, Mücevher } \\
\text { ustaları vb. (7312;7313;7316; 7318;7319), Gravürcüler (7321), Işıkçı-Sahne, Stüdyo vb.(7411), } \\
\text { Dekoratif ahşap işçiliği ustaları (7522), Modelistler, Sahne ve Stüdyo Kostümcüleri, Sahne Terzileri, } \\
\text { El Sanatları ustaları vb.(7531; 732;733) }\end{array}$ \\
\hline
\end{tabular}

Not: ISCO-08 Meslek kodları kullanılarak hazırlanmış SGK verilerinden, Florida'nın Yaratıcı Sınıf Tanımlamaları doğrultusunda yazarlar tarafından oluşturulmuştur. 
This Page Intentionally Left Blank 